\title{
STRATEGI PENGUATAN FUNGSI BADAN PERMUSYAWARATAN DESA DALAM PEMBANGUNAN (Studi di Desa Tapulaga Kecamatan Soropia Kabupaten Konawe)
}

\author{
Nurul Rezky Fitriana ${ }^{1}$, Sulsalman Moita ${ }^{2}$, Aryuni Salpiana Jabar ${ }^{3}$ \\ 123Jurusan Sosiologi FISIP Universitas Halu Oleo, Kendari, Indonesia \\ 1Email korespondensi: nurulrezkhy1@gmail.com
}

\begin{abstract}
ABSTRAK
Tujuan penelitian ini adalah (1) untuk mengkaji fungsi Badan Permusyawaratan Desa (BPD) dalam pembangunan di Desa Tapulaga Kecamatan Soropia Kabupaten Konawe (2) untuk mengkaji dan menganalisis strategi penguatan fungsi Badan Permusyawaratan Desa (BPD) dalam pembangunan di Desa Tapulaga Kecamatan Soropia Kabupaten Konawe. Penelitian dilaksanakan di Desa Tapulaga Kecamatan Soropia Kabupaten Konawe, jenis penelitian ini adalah teknik analisis deskriptif kualitatif dengan cara mengumpulkan data dengan pengamatan (Observasi), wawancara (Interview), dan dokumentasi. Data yang diperolehakan disajikan dalam bentuk penjelasan, uraian dan menggambarkan tentang strategi penguatan fungsi BPD di Desa Tapulaga Kecamatan Soropia Kabupaten Konawe. Hasil penelitian menunjukkan bahwa strategi fungsi Badan permusyawaratan desa telah berjalan sesuai dengan fungsinya yaitu 1. Membahas dan Menyepakati Rancangan Peraturan Desa Bersama Kepala Desa, 2. Menampung dan Menyalurkan Aspirasi Masyarakat Desa dan . 3. Melakukan Pengawasan Kinerja Kepala Desa. Dalam hal penguatan fungsi ini dilakukan dengan 4 cara yaitu 1. Sumber daya manusia anggota BPD yang baik 2. Kepemimpinan yang dapat mengkoordinir semua anggotanya 3.Tingkat partisipasi masyarakat yang cukup tinggi dalam mendukung kinerja BPD 4.Program kerja yang jelas dan terarah yang bersinergi dengan pemerintah desa.
\end{abstract}

Kata kunci : Strategi, Fungsi, Badan Permusyawaratan Desa (BPD)

\begin{abstract}
The purpose of this study were 1 . to study the function of village consultative agencies in carrying out in tapulaga village, soropia sub-district konawe district, 2 . to study and analyze strategies to strengthen the function of village consultative agencies in carrying out in tapulaga village, soropia sub-district konawe district. This research was conducted in Tapulaga Village, Soropia Subdistrict, Konawe District. This type of research is a qualitative descriptive analysis technique by collecting data, observations, interviews and documentation. data obtained is presented in the form of explanations, descriptions and illustrate the strategy of strengthening
\end{abstract}


the function of the village consultative agency in Tapulaga village, Soropia sub district, Konawe district. The results of this study indicate that the implementation of the functions of the village consultative agency has been running according to its function, namely: discuss and agree on the village regulation draft with the village head, 2). accommodate and channel the aspirations of the village community and, 3) supervise the performance of the village head. in terms of strengthening this function carried out in 4 ways, namely: 1). good VCA member human resources, 2). leadership that accommodates all members, 3). a high level of community participation in supporting VCA performance, 4). a clear and directed work program that synergizes with the village government.

Keywords: Strategy, Function, Village Consultative Agency (VCA)

\section{PENDAHULUAN}

Indonesia merupakan negara kepulauan yang didalamnya terdapat berbagai macam suku, ras, agama dan budaya. Keberagaman tersebut dapat kita lihat dengan banyaknya desa yang ada di Indonesia. Berdasarkan data Badan Pusat Statistik (BPS) terdapat 83.931 wilayah administrasi setingkat desa di Indonesia pada 2018. Jumlah tersebut terdiri atas 75.436 desa (74.517 desa dan 919 nagari di Sumatera Barat), kemudian 8.444 kelurahan serta 51 Unit Permukiman Transmigrasi (UPT), Satuan Permukiman Transmigrasi (SPT). Hal tersebut merupakan suatu keunggulan yang dimiliki bangsa Indonesia sehingga menjadikan kita sebagai Negara yang multikultural.

Berdasarkan jumlah tersebut tentunya sangat diperlukan adanya lembaga yang dapat membantu peran kepala desa dalam mengelola administrasi di desa. Salah satu lembaga yang membantu kepala desa dalam mengelola desa adalah Badan Permusyawaratan Desa. Secara yuridis, tugas Badan Permusyawaratan Desa mengacu kepada regulasi desa yakni Undang-Undang Nomor 6 Tahun 2014 tentang Desa. Badan Permusyawaratan Desa atau yang disebut dengan nama lain adalah lembaga yang melaksanakan fungsi pemerintahan yang anggotanya merupakan wakil dari penduduk Desa berdasarkan keterwakilan wilayah dan ditetapkan secara demokratis.

Dalam upaya meningkatkan kinerja kelembagaan di tingkat Desa, memperkuat kebersamaan, serta meningkatkan partisipasi dan pemberdayaan masyarakat, Pemerintah Desa dan Badan Permusyawaratan Desa memfasilitasi penyelenggaraan Musyawarah Desa.Pemilihan anggota BPD dilakukan secara 
demokratis, yakni dipilih dari dan oleh penduduk desa yang memenuhi persyaratan calon anggota BPD.

Dalam Permendagri No.110/2016 Badan Permusyawaratan Desa mempunyai fungsi membahas dan menyepakati Rancangan Peraturan Desa bersama Kepala Desa, menampung dan menyalurkan aspirasi masyarakat desa dan melakukan pengawasan kinerja kepala desa. Dari tiga tugas ini sudah jelas BPD adalah lembaga yang memiliki kekuatan dalam menyepakati peraturan desa yang bakal menjadi pedoman pelaksanaan pembangunan desa.

BPD juga memiliki kekuatan untuk menyampaikan aspirasi warga. Penyampaian aspirasi dilakukan melalui beberapa tahap kerja yakni BPD harus melakukan penggalian aspirasi masyarakat, menampung aspirasi masyarakat yang disampaikan ke BPD dan mengelola aspirasi masyarakat sebagai sebuah energi positif dalam merumuskan langkah kebijakan desa.

Sebagai unsur penyelenggara pemerintahan desa, BPD berfungsi sebagai pengawasan kinerja pemerintahan desa, fungsi ini sangat penting guna memastikan program yang telah disepakati bersama dapat dijalankan dengan baik, sesuai tujuan dan sasaran yang telah ditetapkan, namun demikian pelaksanaan pengawasan ini sebaiknya dikembangkan dengan prinsip semangat kebersamaan untuk memajukan dan membangun desa sesuai dengan tugas pokok dan fungsi masing-masing. Pelaksanaan pengawasan yang dimaksud adalah pengawasan terhadap dana desa (Akbal, dkk., 2019), pengawasan terhadap kinerja Bumdes serta proyek-proyek pemerintah yang masuk ke desa.

Penyelenggara pemerintah desa akan tersusun dan semakin terarah lebih baik bahkan lebih maju apabila sesuai dengan strategi yang telah ditetapkan. Konsep strategi dapat diterapkan dalam beberapa cara, misalnya strategi adaptasi petani terhadap lingkungan hidupnya (Tuwu et al., 2021), strategi Ibu Rumah Tangga Penenun dalam meningkatkan pendapatan keluarga (Efendi et al., 2020), strategi perang, strategi pilitik, dan lain-lain. Dalam tulisan ini strategi digunakan untuk penguatan fungsi Badan Permusyawaratan Desa (BPD) dalam pembangunan di Desa Tapulaga Kecamatan Soropia Kabupaten Konawe. Fakta diberbagai lapisan masyarakat desa menunjukan kesadarannya terhadap pemerintah desa yang di dampingi oleh BPD, sehingga masyarakat merasa 
terwakili kepentingannya untuk mencapai pemerintah desa yang lebih bersih dari unsur-unsur KKN. Hal ini berlaku bagi semua desa di Indonesia termasuk daerah otonom Sulawesi Tenggara.

Namun, pada kenyataannya terkadang apa yang telah disepakati pemerintah desa dengan Badan Permusyawaratan Desa tidak sesuai dengan apa yang diinginkan masyarakat sehingga pembentukan peraturan desa hanya menjadi sebuah agenda pemerintah desa yang tidak substantif dan kooperatif atas kepentingan rakyat, yang seharusnya BPD menjadi wadah penyaluran aspirasi masyarakat. Kurangnya sosialisasi peraturan yang dibuat oleh perangkat desa dengan Badan Permusyawaratan Desa yang menjadi permasalahan dalam proses penyusunan dan penetapan peraturan tidak sesuai dengan apa yang diinginkan masyarakat sehingga masih banyak aspirasi yang tidak dapat diakomodir oleh BPD. Hasil penelitian Suaib (2017) menunjukkan bahwa pelaksanaan fungsi BPD telah berjalan namun belum maksimal hal tersebut di akibatkan oleh kurangnya kemampuan sumber daya manusia serta gaji dari anggota BPD yang rendah.

Dengan demikian penyelenggaraan pemerintah desa termasuk pemerintah desa di Desa Tapulaga Kecamatan Soropia Kabupaten Konawe harus mengacu pada aturan pemerintah yang ditetapkan. Oleh karena itu BPD sebagai lembaga legislasi dalam pemerintahan desa diharapkan benar-benar menjalankan sebagaimana yang sudah ditetapkan. Akan tetapi fakta dilapangan terdapat perbedaan pendapat dalam hal kinerja BPD yang ada di Desa Tapulaga ada yang menganggap BPD telah berjalan sesuai dengan tugas dan fungsinya dan ada pula yang menganggap BPD di desa tersebut tidak maksimal. Keberhasilan pembangunan berkat kerjasama dengan pemerintah desa dapat terlihat dari berbagai sarana dan prasarana yang telah dibangun diantaranya pendirian puskesmas pembantu, pembangunan perpustakaan desa, pembangunan rumah layak huni, pendirian dermaga, balai desa, perpipaan air bersih, sumur bor, dan lain sebagainya. Capaian tersebut tentu merupakan hasil kolaborasi antara pihak BPD dengan kepala desa yang telah menyusun rencana kerja yang cukup baik.

Atas dasar itulah sehingga penulis akan meneliti lebih lanjut lagi mengenai fungsi Badan Permusyawaratan Desa (BPD) dalam Pelaksanaan 
pembangunan serta strategi penguatan fungsi Badan Permusyawaratan Desa (BPD) dalam pembangunan di Desa Tapulaga Kecamatan Soropia Kabupaten Konawe.

\section{METODE PENELITIAN}

Penelitian ini dilaksanakan di Desa Tapulaga Kecamatan Soropia Kabupaten Konawe.Pemilihan lokasi ini didasarkan atas pertimbangan bahwa pada lokasi tersebut terdapat pelayanan fungsi serta strategi penguatan Badan Permusyawaratan Desa. Tipe penelitian ini adalah deskriptif kualitatif. Deskriptif kualitatif bertujuan memperoleh gambaran seutuhnya mengenai suatu hal menurut pandangan manusia atau objek yang diteliti. Penelitian kualitatif berhubungan dengan ide, persepsi, pendapat atau kepercayaan dari orang yang diteliti yang semuanya tidak dapat diukur dengan angka.

Dalam menentukan informan dilakukan dengan menggunakan teknik purposive sampling, artinya sampel sengaja dipilih berdasarkan kriteria yang telah ditetapkan sesuai dengan tujuan penelitian. Adapun Informan dalam penelitian ini terdiri dari kepala desa, 5 orang anggota BPD, 4 orang tokoh masyarakat, dan 5 orang masyaraka sehingga keseluruhan jumlah informan dalam penelitian ini adalah 15 orang. Jenis data yang akan digunakan dalam penelitian ini yakni terdiri dari data kualitatif dan data kuantitatif. Data kualitatif adalah jenis data yang sifatnya tertulis maupun lisan dalam rangkaian kata-kata atau kalimat. Sedangkan data kuantitatif, yakni jenis data yang sifatnya angka-angka yang dapat dihitung matematis.

Adapun sumber data dalam penelitian ini, yaitu data primer dan data sekunder. Data primer merupakan data yang dibuat oleh peneliti untuk maksud khusus menyelesaikan permasalahan yang sedang ditanganinya, data primer yang didapat dalam penelitian ini yaitu hasil wawancara menggunakan panduan wawancara yang disusun oleh peneliti guna mendapatkan data dari informan. Data Sekunder adalah yaitu data yang dikumpulkan untuk melengkapi data primer yang diperoleh dari dokumentasi atau studi kepustakaan yang terkait dalam permasalahan yang diteliti meliputi bukubuku, literatur, artikel, jurnat serta situs di internet yang berkenaan dengan penelitian yang dilakukan. 
Teknik pengumpulan data yang digunakan yaitu teknik penelitian lapangan (field research), yaitu penelitian yang dilakukan secara langsung terhadap objek penelitian di lapangan. Penelitian ini meliputi teknik: (1) Observasi (pengamatan), merupakan perhatian terfokus pada gejala, kejadian atau sesuatu dengan maksud menafsirkannya, mengungkapkan faktor-faktor penyebabnya, dan menemukan kaidah-kaidah yang mengaturnya. (2) Wawancara (interview), yaitu teknik pengumpulan data dengan cara mencari data sedetail mungkin dan mengungkap jawaban jujur dari subjek penelitian dan informan dalam memberikan informasi yang dibutuhkan. Dokumentasi, yaitu teknik pengumpulan data yang tersedia berbentuk suratsurat, catatan harian, foto dan sebagainya yang relevan dalam penelitian ini.

Adapun teknik analisis data yang digunakan untuk menganalisa penelitian ini adalah analisis deskriptif kualitatif, dengan teknik ini setelah data terkumpul dilakukan analisa melalui tiga komponen yaitu reduksi data, penyajian data dan penarikan kesimpulan dengan verifikasinya. Ketiga komponen ini saling berinteraksi dan berkaitan satu sama lain sehingga tidak dapat dipisahkan dari kegiatan pengumpulan data, oleh karenanya analisa data dapat dilakukan sebelum, selama dan setelah proses pengumpulan data di lapangan.

\section{PEMBAHASAN}

\section{Fungsi Badan Permusyawaratan Desa Dalam Pembangunan}

\section{Fungsi BPD Dalam Membahas dan Menyepakati Rancangan Peraturan Desa Bersama Kepala Desa}

Perancangan peraturan desa di Desa Tapulaga berdasarkan aspirasi masyarakat dan kebutuhan desa. Aspirasi masyarakat ini kemudian dirapatkan kembali dengan internal BPD untuk mengkaji mana yang perlu dimuat dalam dokumen Rencana Pembangunan Jangka Menegah Desa (RPJMD) dan Rencana Kerja Pemerintah Desa (RKP) untuk di Perdeskan Sebelum diusulkan dalam rapat bersama pemerintah desa. RPJM Desa adalah suatu kerangka dalam mewujudkan tujuan pembangunan enam tahun. Dokumen RPJM Desa adalah rencana pembangunan desa yang pelaksanaan operasionalnya dijabarkan 
melalui Rencana Kerja Desa (RKP Desa). RKP Desa secara Teknis adalah pedoman untuk mewujudkan arah pembangunan desa selama satu tahun.

Dalam pembahasan ini peneliti berfokus pada peran BPD dalam membahas dan menyepakati rancangan peraturan desa bersama Kepala Desa.Peran BPD Desa Tapulaga dalam hal pembuatan peraturan desa dapat terlihat pada beberapa Perdes yang telah dibuat yaitu:

1. Perdes Nomor 1 tentang rencana kerja Pemerintah Desa Tapulaga

2. Perdes Nomor 2 tentang petunjuk teknis rumah sehat

3. Perdes Nomor 3 tentang bantuan pembangunan rumah tidak layak huni

4. Perdes Nomor 4 tentang larangan penangkapan ikan

Dari beberapa Perdes tersebut telah dilaksanakan dan yang paling ditegaskan untuk dilaksakan dan mempunyai konsekuensi yaitu Perdes Nomor 4 tahun 2018 tentang larangan penangkapan ikan yang merusak lingkungan. Pada Pasal 17 Perdes Desa Tapulaga Menerangkan bahwa diseluruh kawasan laut Tapulaga dilarang keras melakukan kegiatan penagkapan ikan yang merusak lingkungan yaitu dengan menggunakan bahan beracun, obat bius, cantrang dan atau bom ikan.

Peran BPD dalam membahas dan menyepakati rancangan peraturan desa bersama kepala desa terhadap perencanaan program pembangunan di desa Tapulaga merupakan keputusan bersama dengan Pemerintah Desa dimana dalam merumuskan rencana pembangunan. Kepala Desa bekerja sama dengan Badan Permusyawaratan Desa (BPD) sehingga pelaksanaan pembangunan yang telah direncanakan lebih terarah sesuai dengan aspirasi masyarakat dan ditetapkan oleh Kepala Desa dan BPD dalam Rencana Kerja Pemerintah Desa (RKPTDesa). Selanjutnya, Peran BPD dalam Penyusunan RKPDesa yaitu dengan melibatkan dua anggota BPD dalam keanggotaan Tim Penyusunan RKPDesa yang disebut sebagai Tim II sehingga BPD terlibat langsung dalam proses Penyusunan RKPDesa di Desa Tapulaga.

Hal yang menarik dalam penelitian ini adalah selain BPD berperan dalam membahas dan merancang peraturan desa, BPD juga mengambil sejumlah kebijkan terutama dalam perencanaan program pembangunan desa Tapulaga. Kebijakan pada umumnya dianggap sebagai pedoman untuk bertindak atau saluran berpikir. Pengambil kebijakan memiliki peran penting 
dalam merencanakan suatu pembangunan di desa. Terutama dalam menjembatani masalah dengan menjelaskan apa yang dapat dan tidak dapat dilakukan untuk mengejar pencapaian pembangunan yang telah direncanakan. Terkait dengan hal ini, peran BPD dalam mengambil kebijakan terhadap perencanaan program pembangunan yang dimuat dala RKP Desa di Desa Tapulaga merupakan kesepakatan bersama dengan pemerintah desa dimana dalam merumuskan rencana pembangunan Kepala Desa bekerja sama dengan BPD. Dalam setiap pelaksanaan program pembangunan selalu diadakan pertemuan internal BPD bersama Pemerintah Desa untuk menyepakati pedoman yang digunakan sebagai petunjuk teknik dan dasar rencana dalam pembangunan.

\section{Fungsi BPD Dalam Menampung Aspirasi Masyarakat}

Dari temuan penelitian ini ada dua jenis pendekatan dalam menampung aspirasi, yakni top down dan bottom-up. Untuk bottom-up tersedia mekanisme penjaringan pendapat dari bawah melalui forum-forum seperti koordinasi dengan organisasi-organisasi di pedesaan. Dalam perjalanannya ide-ide masyarakat ini kemudian harus dipadukan dengan berbagai dokumen seperti pola dasar (poldas) pembangunan yang berkarakter top down. Dalam prakteknya, pendekatan top down lebih sering terjadi atas ide yang berasal dari atas mengatasnamakan masyarakat desa.

Aspirasi masyarakat pada umumnya melibatkan level bawah dalam menyuarakan aspirasi kepada BPD. Aspirasi digunakan dalam pengambilan keputusan BPD disesuaikan dengan kondisi masyarakat. Pengambilan keputusan dilakukan melalui pertemuan yang melibatkan masyarakat, kepala desa dan BPD. Hal ini menandakan bahwa partisipasi masyarakat merupakan hal mendasar dalam proses menampung aspirasi masyarakat desa (Muslimin, et al., 2020).

Dalam rangka menampung aspirasi masyarakat dilakukan dengan menggunakan strategi-strategi tertentu. Salah satunya adalah dengan mengadakan musyawarah yaitu dimulai dari musyawarah tingkat dusun, musyawarah tingkat desa dan musyawarah tingkat tinggi di desa atau musrembang desa. Tujuan diadakan musyawarah tersebut untuk menampung 
usulan-usulan masyarakat sebagai rencana program pembangunan yang akan dilaksanakan berdasarkan skala prioritas. Selain itu BPD berperan aktif dalam mengambil keputusan terkait dengan rencana program pembangunan di Desa Tapulaga.

\section{Fungsi BPD Dalam Pengawasan Kinerja Kepala Desa}

BPD Desa Tapulaga selalu melakukan pengawasan terhadap kinerja pemerintah desa secara umum. BPD dalam melakukan pengawasan terhadap kinerja kepala desa sudah terlaksana dengan baik, hal ini didorong oleh faktor koordinasi dan kerjasama antar BPD dengan pemerintah Desa Tapulaga. Oleh karena itu dalam melaksanakan fungsi pengawasan lembaga BPD di Desa Tapulaga dapat mempertimbangkan beberapa aspek yang berhubungan dengan fungsi tersebut termasuk koordinasi dengan mitra kerjanya yaitu kepala desa sebagai objek yang diamati.

Pengawasan mencakup mengevaluasi pelaksanaan kerja dan jika perlu memperbaiki apa yang sedang dikerjakan untuk menjamin tercapainya hasilhasil menurut rencana. Mengevaluasi pelaksanaan kerja merupakan kegiatan untuk meneliti dan memeriksa pelaksanaan tugas-tugas perencanaan semula betul-betul dikerjakan sekaligus mengetahui terjadinya penyimpangan, penyalahgunaan, kebocoran, kekurangan dalam melaksanakan tugas-tugasnya.

Fungsi BPD dalam pengawasan kinerja kepala desa bertujuan untuk menjaga keterlibatan dan kelancaran sistem pemerintahan desa dibawah kendali kepala desa. Ketertiban dalam artian masing-masing elemen penyelenggara pemerintahan desa dapat bekerja dengan baik sesuai dengan rencana yang telah ditetapkan dalam peraturan perundangan. Dilaksanakannya pengawasan diharapkan akan membawa manfaat dalam menjamin terwujudnya kepuasan masyarakat terhadap kinerja pemerintah desa dan menjamin ketetapan pelaksanaan tugas sesuai dengan rencana yang telah ditetapkan.

\section{Strategi Penguatan Fungsi Badan Permusyawaratan Desa (BPD)}

Pemerintah desa merupakan bagian yang tidak terpisahkan penyelenggaraan Negara Kesatuan Republik Indonesia (NKRI). Pemerintah desa memiliki peran strategis sebagai ujung tombak dalam mencapai tujuan 
Negara sebagaimana yang diamanatkan dalam konstitusi. Seperti halnya pada pemerintahan pusat dan pemerintahan daerah, penyelenggaran pemerintah desa juga dilengkapi dan dijalankan oleh lembaga pemerintahan yaitu lembaga eksekutif dan lembaga legislative. Lembaga eksekutif desa yang dimaksud adalah kepala desa dan perangkatnya dan lembaga legislatif dipegang oleh Badan Permusyawaratan Desa (BPD). Dalam sistem pemerintahan desa, semuanya akan berjalan efektif apabila unsur-unsur atau lembaga-lembaga pemerintahan desa berjalan dengan baik. Jika ada unsur atau bagian dari sistem penyelenggara Negara tidak mampu melaksanakan tugas dan fungsinya sesuai dengan perundang-undangan maka akan menghambat jalannya pemerintahan desa. Berikut ini akan dijelaskan mengenai Strategi Penguatan fungsi Badan Permusyawaratan Desa (BPD) di Desa Tapulaga Kecamatan Soropia Kabupaten Konawe.

\section{Kriteria Sumber Daya Manusia Anggota BPD}

Sumber daya manusia (SDM) adalah salah satu faktor yang sangat penting bahkan tidak dapat dilepaskan dari sebuah organisasi. Baik institusi maupun perusahaan. Sumber daya manusia juga merupakan kunci yang menentukan perkembangan suatu lembaga. Pengurus Badan Permusyawaratan Desa di Desa Tapulaga Kecamatan Soropia Kabupaten Konawe berdasarkan hasil wawancara yang dilakukan memiliki kualitas sumber daya manusia yang cukup baik. Hal ini dapat terlihat dari stukrtur pendidikan yang dimiliki oleh pengurus BPD di desa tersebut dimana jenjang pendidikan terendah yang dimiliki adalah tamatan Sekolan Menengah Atas dan paling tinggi adalah Strata 1. Hal tersebut sangat penting mengingat kemampuan dalam mengelola suatu organisasi juga sangat dipengaruhi oleh tingkat pendidikan yang dimiliki oleh seseorang. Hal ini kemudian yang menjadi dasar dari kemampuan mereka mengelolah suatu badan dalam hal ini Badan Permusyawaratan Desa.

\section{Kepemimpinan}

Kepemimpinan sebagai kegiatan memandu, menuntun, membimbing, membangun, memberi atau mengembangkan motivasi kerja, mengemudikan organisasi, menjalin jaringan-jaringan komunikasi organisasi yang baik, dan membawa para pengikutnya kepada sasaran-sasarn yang ingin dituju sesuai dengan ketentuan waktu dan perencanaan. Asas kepemimpinan sangat penting 
karena kepemimpinan akan memproduksi hasil yang baik dan yang bermanfaat dalam kaitannya dengan efesiensi organisasi. Sedangkan fungsi kepemimpinan menjadi penting karena fungsi tersebutlah yang menjadi indikator apakah kepemimpinan tersebut berjalan optimal atau tidak.

Peran pimpinan BPD di Desa Tapulaga Kecamatan Soropia Kabupaten Konawe terlihat dalam perannya sebagai mitra kerja Kepala Desa dalam membantu menyelenggarakan program pembangunan sehingga proses pembangunan tersebut dapat berjalan sebagaimana mestinya sesuai dengan perencanaan yang telah ditetapkan bersama dengan masyarakat dan pemerintah setempat. Hal tersebut menujukkan bahwa kemampuan koordinasi penting dilakukan dalam menunjang berjalannya program kerja dalam suatu desa. Peran pimpinan BPD juga dapat memberikan manfaat yang lebih konkrit dalam upaya memberdayakan anggotanya. Mereka bersama-sama menyusun program perencanaan pembangunan melalui musyawarah mufakat dengan menghasilkan pembangunan yang telah disepakati oleh masyarakat dan aparat desa yang lain.

\section{Partisipasi Masyarakat}

Menurut Slamet dalam Suryono (2001) Partisipasi masyarakat dalam pembangunan diartikan sebagai ikut sertanya masyarakat dalam pembangunan, dan ikut serta dalam memanfaatkan dan menikmati hasil pembangunan. Masyarakat diharapkan untuk dapat berpartisipasi dalam membangun serta menjaga lingkungan dimana mereka berada. Untuk mensukseskan gerakan pemberdayaan masyarakat tersebut, pemerintah membentuk beberapa lembaga seperti Badan Permusyawaratan Desa (BPD), Lembaga Pemberdayaan Masyarakat (LPM), Dan Karang Taruna sebagai wadah dalam mendorong komunitas lokal dalam berpartisipasi dan menjunjung solidaritas bersama.

Menganalisa pandangan tersebut diatas terlihat bahwa pelaksanaan pembangunan di Desa Tapulaga Kecamatan Soropia Kabupaten Konawe, berintikan upaya menumbuhkan partisipasi aktif seluruh masyarakat dalam proses pembangunan. Dengan demikian, keberhasilan pembangunan desa akan tercermin dengan keterlibatan dan peran serta antara Badan Permusyawaratan 
Desa (BPD), Pemerintah Desa, dan masyarakat untuk mengambil bagian dalam pelaksanaan pembangunan desa disegala bidang.

Partisipasi masyarakat Desa Tapulaga dalam mendukung kebijakan pemerintah desa dan menguatkan kinerja Badan Permusyawaratan desa dapat tercermin melalui keterlibatan dan tanggung jawab dalam pembangunan secara kolektif guna mewujudkan pembangunan secara optimal. Partisipasi masyarakat dan BPD dalam desa merupakan kebutuhan yang sangat esensial karena keterlibatan masyarakat merupakan syarat mutlak bagi berhasilnya suatu pembangunan. Suksesnya pembangunan desa sangat ditentukan oleh partisipasi seluruh pihak yang terlibat dalam hal ini seluruh lapisan masyarakat dalam hal ini BPD, pemerintah desa, dan masyarakat.

\section{Program Kerja}

Di Desa Tapulaga Kecamatan Soropia Kabupaten Konawe, Badan Permusyawaratan Desa (BPD) memiliki program kerja yang terbagi dalam beberapa bidang. Misalnya dibidang pemerintahan program kerjanya antara lain menyiapkan dan melaksakan pemilihan kepala desa, menggagas lahirnya peraturan desa tentang APBDes secara transparant, mendorong budaya demokrasi. Dibidang ekonomi program kerjanya antara lain menggagas lahirnya BUMdes, menata lembaga ekonomi bersama pemerintah desa, mendorong lahirnya usaha kecil dalam masyarakat. Serta dalam bidang kemasyarakatan program kerjanya yaitu menumbuh kembangkan rasa cinta terhadap desa, mendorong lahirnya lembaga kemasyarakatan desa sebagai unsur pembangunan pemerintahan desa serta berusaha untuk mengayomi serta melestarikan budaya dan kebiasaan positif yang berdampak pada pembangunan.

Dengan demikian dapat dikatakan bahwa program kerja yang dilakukan oleh Badan Permusyawaratan Desa Tapulaga telah dilaksanakan sepenuhnya dan telah berjalan sesuai dengan apa yang telah direncanakan. Program kerja menjadi komponen penting bagi organisasi dalam mencapai sebuah tujuan. Didalam sebuah organisasi atau badan terdapat program kerja yang telah disusun sedemikian rupa untuk dilaksanakan sehingga dapat membantu sebuah organisasi untuk mencapai tujuan utama. Dengan adanya program 
kerja maka setiap anggota atau tim yang melakukan pekerjaan dapat bekerja secara lebih efektif dan terstruktur.

\section{PENUTUP}

Berdasarkan pembahasan dalam penelitian ini maka dapat disimpulkan bahwa:

1. Pelaksanaan fungsi Badan Permusyawaratan Desa (BPD) dalam pembangunan di Desa Tapulaga Kecamatan Soropia Kabupaten Konawe berjalan sangat baik, hal ini dapat terlihat pada terlaksananya kegiatan yang berhubungan dengan fungsi BPD yang sesuai dengan UUD. Misalnya:

a. Dari segi membahas dan menyepakati rancangan peraturan desa yaitu menerbitkan beberapa Perdes.

b. Dalam Fungsi menampung aspirasi BPD Desa Tapulaga mempunyai tahapan yang jelas yakni penyelenggaraan Musyawarah Dusun bersama Kepala Dusun dan selanjutnya penyelenggaraan Musyawarah desa Guna Menyampaikan kesepatakatan yang telah dilakukan dalam Musyawarah dusun.

c. Dari fungsi pengawasan kinerja Kepala Desa dapat terlihat pada koordinasi yang dilakukan bersama Kepala Desa dalam hal pembangunan desa.

2. Strategi penguatan fungsi Badan Permusyawaratan Desa (BPD) dalam pembangunan di Desa Tapulaga Kecamatan Soropia Kabupaten Konawe yaitu pemilihan sumber daya manusia yang handal yang terdiri atas 2 orang sarjana (S1) dan 3 orang tamatan SMA, kepemimpinan dapat memanajemen anggota dan masyarakat dengan baik utamanya dalam pembahasan suatu kebijakan dan rapat desa, partisipasi masyarakat yang tinggi yang dapat terlihat pada dukungan masyarakat terhadap kinerja BPD dan program kerja yang jelas dan terarah baik jangka panjang maupun jangka pendek. 


\section{DAFTAR PUSTAKA}

Akbal, H., Bahtiar, Upe, A. (2019). Habitus Multi Aktor dalm Praktik Sosial Pembangunan Perdesaan Melalui Alokasi Dana Desa di Kecamatan Wakorumba Selatan Kabupaten Muna. Publica: Jurnal Administrasi Pembangunan dan Kebijakan Publik, 10 (2): 116-124.

Arsy, Muhammad, 2016.Fungsi Badan Permusyawaratan Desa (BPD) Serta Pola Hubungan dengan Pemerintah Desa Dalam Penyelenggaraan Pemerintahan. Jurnal Siasat, Vol. 10 (2).

Efendi, E., Tuwu, D., \& Tanzil, T. (2020). Strategi Ibu Rumah Tangga Penenun Kain Sarung Muna Dalam Upaya Meningkatkan Pendapatan Rumah Tangga Di Desa Lapolea Kecamatan Barangka Kabupaten Muna Barat. Jurnal Kesejahteraan Dan Pelayanan Sosial, 1(1), 48-60.

https://doi.org/http://dx.doi.org/10.52423/jkps.v1i1.10871

Permendagri No.110/2016 Badan Permusyawaratan Desa mempunyai fungsi membahas dan menyepakati Rancangan Peraturan Desa bersama Kepala Desa,

Hasibuan, Melayu, S.P, 1994. Manajemen Sumber Daya Manusia. Erlangga, Jakarta.

Kartono, Kartini, 1993. Kepemimpinan dan Pemimpin, Rajawali Pres, Jakarta.

Muslimin, Arsyad, M., \& Sarmadan. (2020). Participation of Community in Rural Development in Oengkolaki Village Mawasangka District Central Buton Regency. Indonesian Journal of Social and Environmental Issues (IJSEI), 1(1), 33-38.

Nawawi, 2009.Pembangunan dan Problema Masyarakat: Kajian, Konsep, Model, Teori, dari Aspek Ekonomi dan Sosiologi. Putra Media Nusantara. Surabaya.

Peraturan Pemerintah Nomor 72 Tahun 2005 Tentang Desa

Peraturan Pernerintah Nomor 43 Tahun 2014 tentang Peraturan Pelaksanaan Undang-Undang Nomor 6 Tahun2014

Suaib, 2018. Analisis Penguatan Fungsi Badan Permusyawaratan Desa (BPD) di Desa Karyamukti Kabupaten Gorontalo, Journal of Government \& Political Studies, Vol 1 (1).

Suryono, Agus, 2001. Teori dan Isi Pembangunan, UNM Pres, Malang.

Tuwu, D., Supriyono, \& Arsyad, M. (2021). Farmer Adaptation Strategy to Their

$$
\text { JKPS --- } 70
$$


Environment in the Village of Makoro Binongko Wakatobi. Indonesian Journal of Social and Environmental Issues (IJSEI), 2(1), 7-13. https://doi.org/10.47540/ijsei.v2i1.66

Undang-Undang Nomor 6 Tahun 2014 TentangDesa.

Widjaja, HAW. 2012. Otonomi Desa: Merupakan Otonomi Yang Asli, Bulat Dan Utuh. PT RajaGrafindo Persada. Jakarta. 